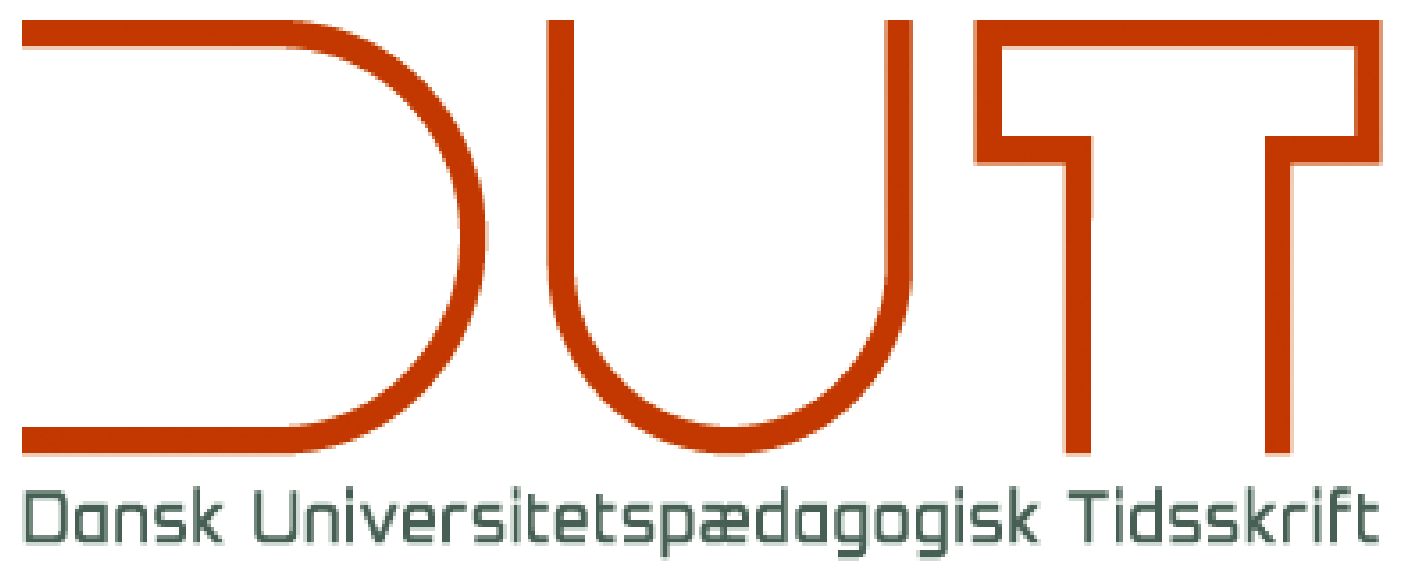

Tema

Undervisningens teknologier og teknikker

Årgang 15 nr. 28 / 2020

Titel

“Den varme stol". En model for peer-feedback i kollektiv vejledning

Forfattere

Sidetal

Udgivet af

URL

Gitte Wichmann-Hansen, Tine Wirenfeldt Jensen, Mia Skytte O'Toole

$71-85$

Dansk Universitetspædagogisk Netværk, DUN

> http://dun-net.dk/

Betingelser for brug af denne artikel

(C) Copyright
Denne artikel er omfattet af ophavsretsloven, og der må citeres fra den. Følgende betingelser skal dog være opfyldt:

- Citatet skal være i overensstemmelse med "god skik"

- Der må kun citeres „i det omfang, som betinges af formålet“

- Ophavsmanden til teksten skal krediteres, og kilden skal angives ift. ovenstående bibliografiske oplysninger.

DUT og artiklens forfatter 


\title{
"Den varme stol". En model for peer-feedback i kollektiv vejledning
}

\author{
Gitte Wichmann-Hansen ${ }^{\mathrm{a}, 1}$, Tine Wirenfeldt Jensen ${ }^{\mathrm{b}}$, Mia Skytte O'Toole \\ aCenter for Undervisning og Læring, Aarhus BSS, Aarhus Universitet \\ ${ }^{b}$ METoDo og SDU Universitetspædagogik, Syddansk Universitet \\ 'Psykologisk Institut, Aahus BSS, Aarhus Universitet
}

Faglig artikel, fagfællebedømt

\begin{abstract}
I artiklen præsenteres en model for, hvordan peer-feedback kan organiseres i kollektiv specialevejledning. Modellen betegnes "den varme stol" og er nytænkende, fordi den sætter fokus på den, der giver feedback, frem for den, der modtager feedback. Modellens centrale pædagogiske greb er dialog, hvorigennem vejlederen støtter den feedback-givende studerende i at udvikle kriterier for teksten med afsæt i læserbaseret feedback. Desuden gør vejlederen de udviklede kriterier til genstand for fælles diskussion med den tekstproducerende studerende og de øvrige deltagere. Med inddragelse af relevant forskningslitteratur argumenterer vi for, at modellen kan: 1. understøtte de studerende $\mathrm{i}$ at oparbejde akademiske skrivekompetencer, 2. fremme studerendes selvstændighed ved at invitere dem ind $i$ en aktiv position i vejledningsrummet samt 3. understøtte vejlederens dialogiske praksis og bygge bro mellem funktionen som procesvejleder og faglig vejleder. Artiklen henvender sig til vejledere, som ønsker at afprøve kollektiv vejledning og peer-feedback eller forfine deres nuværende praksis.
\end{abstract}

\section{Indledning}

Kollektiv vejledning har mange forskellige navne og formater: klyngevejledning, kollektiv akademisk vejledning, specialekollokvier m.m. Fælles for de mange betegnelser er, at vejledningen organiseres kollektivt, dvs. at vejlederen mødes med flere studerende samtidig, og at de studerende skriver på forskellige opgaver - i modsætning til gruppevejledning, hvor de studerende skriver på samme opgave (Rienecker, Wichmann-Hansen \& Stray Jørgensen 2019, s. 197).

De seneste år er kollektiv vejledning blevet en mere udbredt vejledningsform. Det skyldes primært, at vejledning og opgaveskrivning på de videregående uddannelser i stigende grad er kommet under pres - økonomisk og tidsmæssigt. Dels har Fremdriftsreformen medført et pres i forhold til hurtigere gennemførelse, hvilket har skabt et behov for at understøtte studerendes skriveprocesser (Jensen, Bay \& Andersen 2016). Kollektivisering af vejledningen er $i$ den forbindelse blevet set som en vej til at skabe øget fremdrift i studerendes skrivning, fordi kollektiv vejledning indebærer fælles og aftalte deadlines forløbende tekstudkast (Nordentoft, Hvass, og Mariager-Anderson 2018). Dels er vejledningsopgaven i mange fag blevet underlagt strammere vilkår i form af færre normerede timer og flere studerende, hvilket har skabt øget interesse for, hvordan man kan effektivisere vejledernes tid. Kollektiv vejledning har bl.a. vist sig at have nogle klare fordele for vejlederne i form af mere ro og overblik, færre

${ }^{1}$ Kontakt: gwh@au.dk 
gentagelser og mere fokus på at kondensere end på at detail-producere feedback (Rienecker et al 2019).

Forklaringen på den øgede udbredelse og interesse for kollektiv vejledning skal dog ikke kun findes i nye strukturelle og økonomiske forhold. En anden, og fra et fagligt perspektiv mere interessant forklaring, er det læringsmæssige potentiale i kollektiv vejledning. Vejledningsformen inddrager peer-feedback og dialog, som har en række faglige og sociale gevinster for de studerende.

Forskningen tyder på, at peer-feedback er en effektiv metode til at træne studerende i at genkende og anvende videnskabelighedskriterier og dermed øge deres kompetencer til at skrive akademiske opgaver (Topping 2017). Peer-feedback bidrager også til at udvikle studerendes selvregulerende adfærd (Nicol \& Macfarlane-Dick, 2006) forstået som evnen til på egen hånd at monitorere og regulere en række processer involveret i læring. Dette er særligt ønskeligt i opgaveskrivning, hvor studerende forventes at arbejde selvstændigt og at 'diagnosticere' kvaliteten af deres eget arbejde i takt med, at skrivningen skrider frem. Når studerende - som feedbackgivere - læser og vurderer medstuderendes tekster, skærper det blikket på både kriterier og deres egen tekst. De justerer og redigerer deres eget materiale ud fra de styrker og mangler, de har identificeret i de andres materiale (Ibid).

Derudover viser forskningen, at dialogen mellem peers og vejleder i et kollektivt møde er en effektiv 'øvebane' for at lære at argumentere for sin sag, begrunde sin kritik og lytte med respekt til andres kritik. Det imiterer en autentisk forskningspraksis, som kendes fra fx peerreviews og andre professionelle samtaler mellem forskningskollegaer, og dermed bidrager dialogen til, at de studerende effektivt socialiseres ind i det faglige diskursfællesskab (Samara 2007).

Endelig er det veldokumenteret, at der er sociale gevinster ved kollektiv vejledning, idet studerende oplever at være mindre alene med deres opgaver og at få mere personlig støtte i skriveprocessen. I kollektiv vejledning mødes de med andre studerende, der er i samme båd, og som med stor sandsynlighed står med nogle af de samme typer udfordringer, som de selv gør. Det giver en god anledning til at hjælpe hinanden med strategier til at overkomme skriveblokeringer, nervøsitet, stress eller andre følelsesmæssige aspekter af arbejdet (Nordentoft, Thomsen og Wichmann-Hansen 2013).

Kollektiv vejledning har således vist sig i praksis at kunne imødekomme nogle aktuelle udfordringer på de videregående uddannelser og er samtidig en teoretisk velfunderet vejledningsform. Alligevel er individuel vejledning stadig den mest udbredte, kendte og etablerede form for vejledning. Det er den sandsynligvis, fordi kollektiv vejledning medfører et kulturskifte for vejledere og studerende, der er vant til individuel vejledning (Nordentoft et al 2018). Vejlederens rolle forskydes fra at være den eneste, der giver feedback, til at være facilitator af peerfeedback. De studerendes rolle forskydes fra kun at være modtagere af feedback til også at være feedbackgivere. De studerende skal således være villige til at indgå i en mere aktiv position og til at investere tid i deres medstuderendes projekter. De skal forstå, at de kan lære mere af at give end at få feedback, og at vejlederen ikke er den eneste ressource eller 'kun' en faglig ekspert. Tilsvarende kan vejledningsformen være vanskelig for vejlederne, især de uprøvede vejledere, fordi formen kræver et overblik og en stringens samt potentielt en evne til at rumme flere studerendes processer på én gang. Kollektiv vejledning kræver derfor en række velovervejede didaktiske greb for at lykkes og for at udnytte det potentiale, der ligger i, 
at studerende investerer tid og kræfter i at give og modtage feedback på hinandens arbejde (Wanner \& Palmer 2008).

Formålet med denne artikel er at præsentere en model for, hvordan peer-feedback i kollektiv specialevejledning konkret kan organiseres, så dette potentiale bedre kan udnyttes. Modellen er udviklet på en psykologisk kandidatuddannelse men kan anvendes på tværs af fagdiscipliner. Læseren får præsenteret den konkrete model med detaljerede anvisninger for, hvordan den kan implementeres i praksis, samt forskningsbaserede og teoretiske argumenter for modellens grundlag. Artiklen henvender sig således til vejledere, som ønsker at afprøve kollektiv vejledning eller forfine deres nuværende brug af peer-feedback.

Modellen skal forstås som et bidrag til en udvidelse af den kollektive vejleders værktøjskasse en værktøjskasse, der kan indeholde mange forskellige didaktiske greb (se fx Jensen 2015). Modellen er dermed ikke tænkt som en erstatning for andre måder at organisere kollektiv vejledning på eller for andre måder at facilitere peer-feedback på. Det er den konkrete kontekst og målene for vejledningen, der må afgøre, hvad der i den givne situation er den bedste måde at organisere kollektiv vejledning på.

\section{En model for kollektiv specialevejledning på psykologi}

I det følgende beskrives først baggrund og kontekst for modellen. Dernæst beskrives det samlede specialevejledningsforløb samt fremgangsmåden for de enkelte kollektive vejledningsmøder og endelig de studerendes oplevelse af møderne. Beskrivelsen har til formål at præsentere modellen og dens kontekstuelle forankring i en grad, så det bliver muligt for andre vejledere at inkorporere hele eller dele af modellen i egen vejledningspraksis. Dertil danner beskrivelsen grundlag for diskussionen af modellens styrker og svagheder $\mathrm{i}$ et teoretisk perspektiv.

\section{Baggrund og kontekst}

Modellen blev oprindelig udviklet som en del af et vejledningsforløb for fire specialestuderende på faget psykologi. Vejlederen (artiklens sidsteforfatter) er ansat som lektor med ca. 30 tidligere individuelle specialevejledningsforløb bag sig. På den pågældende institution kan de studerende vælge mellem to formater for deres speciale. Det ene format kan bestå af en tekst på op til 65 sider med enten et teoretisk eller empirisk fokus. Det andet format kan bestå af to artikler, hvor den ene er et review og den anden en empirisk artikel. Det første format vælges langt oftest og anses for at være et 'klassisk' speciale. Bedømmelsen sker alene på baggrund af det skriftlige produkt uden mundtligt forsvar. Til selve vejledningen gives i alt 15 undervisningstimer til vejlederen, hvilket inkluderer forberedelsestid.

Efter fremdriftsreformen i 2013 skulle alle studerende i udgangspunktet skrive deres speciale på 4. semester af deres kandidatstudium. Som en konsekvens af dette besluttede man derfor på instituttet, at alle studerende skulle fordeles fra centralt hold til det pågældende semesters specialevejledere. Dette foregår konkret via studieadministrationen, hvortil de kommende specialestuderende har indgivet deres prioriterede ønsker $\mathrm{i}$ forhold til valg af specialevejleder. Som vejleder på den pågældende institution får man derfor sine specialestuderende i klynger med samme start- og sluttidspunkt. Denne forandring har lokalt givet anledning til øget opmærksomhed på muligheden for at benytte kollektiv vejledning og udnytte den mulighed, det (også) er at have specialestuderende i parallelforløb. Det er p.t. op til vejlederen, om der tilbydes individuel og/eller kollektiv vejledning. Hvordan den enkelte vejleder organiserer vejledningen, kan de studerende læse i et såkaldt vejlederbrev (se fx Wich- 
mann-Hansen \& Jensen, 2013), som de kan orientere sig i, inden de vælger en specifik vejleder.

\section{Det samlede vejledningsforløb}

Vejledningsforløbet bestod af et fælles introduktionsmøde samt fem individuelle vejledningssessioner suppleret med to kollektive vejledninger. På det fælles introduktionsmøde blev de fire studerende præsenteret for hinanden og vejleder. Læringsmålene for specialet blev gennemgået af vejleder og diskuteret i gruppen, hvorefter de studerende præsenterede deres emneområde og eventuel problemformulering. Den individuelle vejledning foregik løbende med cirka 3 ugers mellemrum på baggrund af op til 7 siders tekst sendt til vejlederen to dage forud for et fysisk møde af cirka 45 minutters varighed. De kollektive vejledninger blev præsenteret som et tilbud, men uden mulighed for at konvertere timerne til individuel vejledning. Placeringsmæssigt fandt de to kollektive sessioner sted cirka en måned efter, den officielle specialeperiode begyndte, og cirka en måned inden afleveringsfristen ( $i$ alt et forløb over 4 måneder). Baggrunden for at konvertere noget vejledningstid fra individuel til kollektiv vejledning var primært ønsket om at skabe et forum, hvori de studerende aktivt kunne arbejde med feedback og opøve evnen til at evaluere andres og ultimativt deres egen tekst ud fra et sæt kriterier. Ved at lade de studerende aktivt opdage og udvikle kriterierne sammen var det endvidere et formål, at de fik et fælles sprog at støtte sig til gennem deres specialeproces, der kunne bruges på tværs af forskellige emner. Nedenfor beskrives, hvordan de enkelte kollektive vejledningsmøder blev gennemført.

\section{Organisering af peer-feedback på kollektive vejledningsmøder}

Den kollektive vejledning bestod af to vejledningsgange, som hver varede to timer. Første mødegang var fokus på, hvad der kendetegner fremstillingsformen 'redegørelse'. Anden mødegang var fokus på, hvad der kendetegner fremstillingsformen 'diskussion'.

De specialestuderende blev forud for den kollektive vejledning introduceret både mundtligt og skriftligt til formatet for den kollektive vejledning. Her blev det påpeget, at den kollektive vejledning primært havde fokus på videnskabelig akademisk fremstilling. Det specifikke faglige indhold ville således være sekundært. De studerende fik at vide, at brugbare kommentarer i forhold til indholdet var et heldigt biprodukt af den kollektive vejledning, og at det primære formål var at udvikle kriterier for 'den gode redegørelse' og 'den gode diskussion' i en videnskabelig kontekst. Vejledning på det konkrete faglige indhold var forbeholdt de individuelle vejledningsmøder. Dernæst blev det understreget, at den vigtigste opgave for de studerende var at give feedback snarere end af modtage den, og at denne feedback som sagt ikke skulle centrere sig om det faglige indhold. Det konkrete faglige indhold var at betragte som en slags øvebane for den egentlige læringsaktivitet, som netop var at udvikle kriterier for de pågældende akademiske fremstillingsformer, således at studerende derefter kunne anvende disse på egne tekster. Grundidéen til denne form for kollektiv specialevejledning kom fra flere holdundervisningsforløb på kandidatniveau, hvor de studerende i skriftlige evalueringer angav at være glade for et eksplicit fokus på den skriftlige fremstilling.

Som materiale til vejledningen blev alle studerende bedt om at producere to siders tekst enten af redegørende (gang nr. 1) eller diskuterende (gang nr. 2) karakter. Denne tekst deltes via e-mail. Herefter skulle én studerende læse én anden studerendes tekst og notere 1) steder, hvor redegørelsen/diskussionen fungerede godt eller mindre godt, og ikke mindst 2) hvorfor det var tilfældet. Sidstnævnte punkt var selve omdrejningspunktet for den kollektive 
vejledning, hvor svaret blev omformuleret til konkrete kriterier. Alle studerende skulle således alene forholde sig til én anden studerendes tekst, mens vejlederen læste alles tekster. For at understrege, at fokus for vejledningen netop var at udvikle eller formulere kriterier (og ikke at få indholdsmæssig feedback), blev de studerende bedt om ikke at skrive et følgebrev til deres to siders skrivelse eller på anden måde kommentere, hvor de befandt sig i specialeprocessen med dertilhørende specifikke behov. Følgebreve er velegnede til at afdække skribentens feedbackbehov og opfattelse af egen tekst, men her var fokus netop på at udvinde fælles kriterier for redegørelse og diskussion, og et følgebrev ville derfor risikere at være 'støj', som fjernede fokus fra det fælles projekt.

\section{Feedbackgiver placeret $i$ "den varme stol"}

Alle studerende (i dette tilfælde fire) og vejlederen var til stede under de to timers kollektive vejledning. Her blev hver studerende, der skulle give feedback, inviteret til en samtale med vejlederen. Helt konkret foregik det sådan, at vejlederen satte sig fysisk overfor denne ene studerende, der havde læst en anden studerendes tekst. Dermed blev det understreget, at aktiviteten nu skete mellem de to, og at de andre var tilhørere uden taleret. Derefter skiftede turen til en anden studerende, der nu fysisk satte sig overfor vejlederen og drøftede en anden studerendes tekst. På den måde fungerede stolen overfor vejlederen som en slags 'varm stol', hvilket var med til at understrege, at den, der var på arbejde, var den studerende, der gav feedback. "Den varme stol" er en metode, der oprindeligt stammer fra gestaltterapien (Perls, Hefferline \& Goodman, 1950), og som i forskellige fortolkninger har vundet almen udbredelse på en række andre felter. I psykologien tilbyder metoden (meget forenklet) et greb til at sætte det enkelte individs oplevelser og følelser i fokus. Den studerende, der skulle modtage feedback, blev instrueret i at notere sig, hvilke kriterier hun ville være særligt opmærksom på fremadrettet i sin skriveproces.

Siddende over for hinanden gik vejleder og den studerende igennem de to siders tekst og diskuterede elementer, der fungerede godt eller mindre godt, og ikke mindst hvorfor. Vejlederen assisterede den studerende i at formulere konkrete kriterier ud fra hendes læsning og bidrog selv med kriterier om nødvendigt. Den studerende kunne fx sige: “Her fungerer redegørelsen ikke særlig godt, fordi jeg som læser ikke er med på, hvad den studerende vil med denne passage". Vejlederen kunne så svare: "Okay, så du læser denne tekstpassage og bliver i tvivl om, hvad forfatteren vil med dig eller teksten lige præcis her. Hvordan kan vi oversætte dén observation til et kriterium for den gode redegørelse?" Herefter kunne vejlederen og den studerende så tale sig frem til, at et kriterium for den gode redegørelse er, at der ofte er en formålsstyret metatekst, eller at man på anden måde fornemmer, at teksten er pointedrevet.

Efter denne drøftelse mellem den feedbackgivende studerende og vejleder blev den tekstproducerende studerende inviteret til at reflektere over det, hun eller han havde hørt. Dette skete altså under vejleders specifikke instruktion om at reflektere over kriterierne og ikke selve indholdet. Derefter blev de øvrige studerende bedt om at udpege kriterier, som de også havde hæftet sig ved i dialogen mellem vejleder og den feedbackgivende studerende. Hvert møde blev afsluttet med, at vejleder læste de kriterier op, som var kommet frem undervejs i mødet, og som hun havde noteret. Derpå blev alle studerende inviteret til at kommentere og diskutere kriterierne. Vejleder spurgte fx: "Er der nogen kriterier, der overrasker jer? Er der nogen, der mangler at blive noteret?" 
Formatet har visse ligheder med den supervisionsform, der går under navnet 'reflekterende team'. Her fortæller en person om en aktuel problemstilling, eventuelt under ledelse af en supervisor, hvorefter gruppemedlemmer diskuterer problemstillingen. Dette foregår ved, at der tales om problemstillingen og aldrig direkte til supervisanden, som dog typisk til sidst får mulighed for at reflektere over det hørte. Reflekterende teams er en praksis udviklet inden for familieterapien i 1980'erne (Andersen, 1994), som siden har vundet udbredelse på mange andre områder, herunder vejledningsområdet (se fx Nordentoft et al., 2019). Metoden er socialkonstruktivistisk og karakteriseret ved et fokus på dialog, kollektiv meningsskabelse og et fravær af endegyldige svar, og metoden spiller en vigtig rolle i uddannelsen af praktiserende psykologer (Griffith \& Frieden, 2000; Upton \& Trapp, 2010).

\section{Opsamling af foelles kriterier}

Vejlederen sendte efter den kollektive vejledning et opsamlende dokument ud med alle de nedskrevne kriterier. I det følgende gengives de kriterier, som de specialestuderende producerede for fremstillingsformerne "redegørelse" og "diskussion". De er her sat op i en tabel for læsevenlighedens skyld:

- $\quad$ Argument kræver eksplicitte tankerækker

- $\quad$ Der skal 'afsender' på alle påstande

- $\quad$ Kort og tydelig begrundelse for valg

- Hav en logisk struktur/opbygning

- $\quad$ Følg egen kritik op med 1) vurdering og/eller 2) implikationer og/eller 3) forslag til andre tilgange/procedurer

- $\quad$ Vær hele tiden pointedrevet

- Ved empirigennemgang skal der tilstrækkeligt mange af procedurerne med for at forstå konklusionen
- Pas på med talesprog og absolutte termer

- Det er vigtigt med begrebspræcision

- Hold samme akademiske tone/sværhedsgrad teksten igennem

- Brug kursivering, når det tjener formål - for eksempel første gang

- Klarhed i analytiske kategorier

- Tydelige tråde mellem afsnittene

- Hav formålsbeskrivende metatekster

- Rammesætning på plads før fortolkning

- Opsummering demonstrerer forståelse

Tabel 1. Liste over de producerede kriterier for en 'redegørelse' 
- $\quad$ Ramme for diskussionen skal være klar med tydeliggørelse af a) Formål - gerne med støttende metatekst og b) Eventuelle præmisser, som diskussionen 'står på'

- Diskussionen består af argumenter, der i høj grad følger en 'hvis.., så'-logik

- I en diskussion er der ofte flere 'bolde i spil', hvorfor det bliver (endnu mere) vigtigt med tydeliggørelse af de forskellige 'positioner', det være sig en tradition, en teori, et fundeller en pointe
- $\quad$ Når to fænomener eller lignende sammenlignes, skal de behandles med sammenlignende sprog og/eller udsættes for de samme analysekategorier

- $\quad$ En sammenligning følges til dørs med en vurdering, som kommer til at ligne et 'tilfældigt' postulat, hvis det står på skuldrene af en ensidig argumentationsrække

- Vær opmærksom på læsevenligheden, så de forskellige påstande og argumenter følges

Tabel 2. Liste over de producerede kriterier for en 'diskussion'

Vejlederen understregede, at dokumentet var en opsummering af den pågældende vejledning, og at dokumentet ikke udgjorde hverken en udtømmende beskrivelse af, hvad den gode redegørelse/diskussion er, eller et juridisk bindende dokument. Til de formål blev de studerende henvist til publikationer om skriftlig fremstilling mere generelt ( $f x$ Skov, 2008) og den gældende studieordning.

\section{De studerendes oplevelse af de kollektive vejledningsmøder}

I det følgende formidles de studerendes oplevelse af de kollektive vejledningsmøder på baggrund af en evaluering via mail. Det skal bemærkes, at de studerendes oplevelser udelukkende medtages i denne sammenhæng som en del af beskrivelsen af modellens kontekst. De rapporterede oplevelser udgør dermed ikke empirisk belæg for modellens brugbarhed.

Evalueringen fandt sted, inden de studerende havde fået deres karakterer, for at undgå, at de studerendes vurdering blev farvet af deres specialekarakter. Evalueringen var kun så anonymiseret, som det lader sig gøre via mail og med fire studerende. Vejlederen sendte evalueringsspørgsmålene til alle fire studerende på én gang og bad dem om at sende e-mailen internt til hinanden og skrive deres svar ind i e-mailen netop med det formål, at vejlederen ikke ville kunne se, hvem der havde skrevet hvad. På forhånd havde vejlederen sagt, at hun ville have den endelige mail fra en bestemt studerende, sådan at vejlederen heller ikke kunne regne ud, at de sidste kommentarer nødvendigvis kom fra dén studerende. Det blev desuden understreget, at det var $100 \%$ frivilligt at deltage, ligesom de studerende blev informeret om, at deres svar senere ville formidles i en artikel.

De blev bedt om at tage stilling til følgende fem spørgsmål: 1) Hvordan oplevede I den kollektive vejledning? 2) Hvad fungerede godt? 3) Hvad fungerede ikke godt? 4) Hvordan har I brugt pointerne fra vejledningen i jeres skriveproces? 5) Hvilke gode råd har I til at forbedre den kollektive vejledning? 
De studerende var meget positive over for formatet. Alle fire studerende nævnte, at de gerne ville have haft mere kollektiv vejledning, og ingen kunne påpege noget, der ikke fungerede godt. En studerende beskrev desuden det brugbare i at give feedback til en anden og sagde:

Desuden oplevede jeg, at øvelsen med at give feedback til en anden kunne hjoelpe én til at se sin egen opgave med "nye briller.

Særligt blev den kollektive vejledning vurderet nyttig i udformningen af de diskuterende elementer i opgaven, hvor pointerne fra den pågældende vejledningsgang kom til at centrere sig om, hvordan man bygger et argument op i en diskussion. Her beskriver flere studerende at bruge opsummeringen som en slags tjekliste, og en studerende sagde for eksempel:

Dette gav en god ramme, som kunne bruges aktivt i specialeprocessen.

I forhold til mængden af forberedelse udtalte en studerende, at

Det hjalp hertil, at man kun skulle koncentrere sig om at give feedback til én person.

Endelig blev det fremhævet af flere studerende, at formatet også havde sociale fordele, og en studerende skrev:

Herudover fungerede det godt, at vi var en lille gruppe på fire personer og kun loeste én person fra gruppens tekstmateriale.

Denne positive modtagelse af den kollektive vejledning skal ses i lyset af en vis portion skepsis fra de studerende inden forløbet, som nok mest korrekt kan tolkes som en nervøsitet for, at den mindre mængde individuel vejledning ville betyde, at vejlederen ville læse mindre af den enkelte studerendes samlede speciale.

\section{Modellens styrker i et teoretisk perspektiv}

I det følgende argumenterer vi for, at den beskrevne model for peer-feedback i vejledningen har en række styrker. Vi henter de bærende argumenter i forskningslitteraturen om vejledning frem for (kun) at støtte os til empiriske data fra det konkrete forløb, da dataene er begrænset til få studerendes udsagn. Vi peger på, at anvendelse af modellen kan:

1. understøtte de studerende i at oparbejde akademiske skrivekompetencer,

2. fremme studerendes selvstændighed ved at invitere studerende ind i en aktiv og fortolkende position i vejledningsrummet og endelig

3. understøtte vejlederens dialogiske praksis og bygge bro mellem funktionen som procesvejleder og faglig vejleder.

\section{Modellen kan understøtte de studerende i at oparbejde akademiske skrivekompetencer}

Der er på danske universiteter ikke nogen stærk tradition for at undervise i akademisk skrivning som en integreret del af fagene eller i form af deciderede kurser, til trods for at de studerendes skriftlige niveau ofte gøres til genstand for kritik (Jensen, Bay \& Andersen 2016). Faglig skrivning er en social praksis tæt forbundet med de enkelte fags vidensforståelser og de studerendes udvikling af faglig identitet (Lea \& Street 1998), og at lære at skrive i sit fag er dermed både en vej til og en forudsætning for at lære faget og kunne gå i kritisk dialog med det. Ifølge Lea og Street (1998) er kriterier for videnskabelige tekster altså et resultat af kontinuerlige forhandlinger, og de studerende har også en stemme i de forhandlinger. Der er 
dermed ikke tale om, at de studerende blot passivt skal tilegne sig endegyldige kriterier. De faglige undervisere og vejledere indtager derfor en helt central rolle i forhold til at understøtte de studerende i at opbygge akademiske skrivekompetencer. Det kan dog for den enkelte vejleder være vanskeligt at skabe tid og rum til at gøre dette inden for vejledningens rammer. Med denne model skabes rum til som en del af den kollektive vejledning at sætte særligt fokus på akademiske skrivekompetencer forankret i en fagspecifik kontekst. Det sker konkret ved, at der sættes fælles fokus på fremstillingsformer (her "redegørelse" og "diskussion"), hvilket skærper de studerendes bevidsthed om fremstillingsformernes funktion og betydning samt den akademiske genre som helhed. Samtidig skabes der synlig forbindelse til og øget opmærksomhed på studieordningens beskrivelse af krav til specialet, hvori de to fremstillingsformer indgår. Der tages i modellen udgangspunkt i læserbaseret feedback, der er feedback baseret på læserens subjektive og umiddelbare oplevelse af, hvad der fx hæmmerog fremmer læsningen på et helt konkret niveau (Elbow 1998; Hvass \& Heger, 2018). Ved at arbejde med læserbaseret feedback øges de studerendes modtagerbevidsthed (Elbow 1998; Hvass \& Heger, 2018). I modellen samarbejder vejlederen med den studerende, der giver feedback, om at bruge den læserbaserede feedback til at udvikle generelle kriterier for faglige redegørelser og diskussioner. Disse kriterier kan den studerende efterfølgende applicere i sin egen tekst, ligesom kriterierne kan indgå i den faglige individuelle vejledning. De andre studerende inviteres samtidig til aktivt at lytte efter kriterier, så alle studerende engageres i feedbackaktiviteten.

Feedbackforskningen indikerer, at studerende lærer lige så meget - hvis ikke mere - ved at give feedback som ved at modtage den. Den viden om kriterier, der opbygges gennem det aktive arbejde med at give andre feedback, kan den studerende efterfølgende anvende i arbejdet med egne tekster (Nicol, Thomson \& Breslin 2014; Gibbs 1999; Cho \& MacArthur 2011). Hvor det at give feedback nødvendiggør en aktiv indsats, er det muligt passivt at modtage feedback og undlade at handle på den. At involvere de studerende i selv at udvikle kriterier har også en række fordele. Tai et. al. (2018) peger på vigtigheden af, at studerende får mulighed for selv aktivt at diskutere kriterier og standarder, da det vil styrke deres dømmekraft (evaluative judgement) og støtte dem i at tage ejerskab over egen læring. Tilgangen synliggør også, at kriterier er et resultat af kontinuerlige forhandlinger inden for fagfællesskabet, og inviterer de studerende til at tage aktivt del i disse forhandlinger. Der er således gode argumenter for både at organisere peer-feedback-aktiviteter på måder, der understreger læringsudbyttet ved feedbackgivning, og for at invitere de studerende til selv at udvikle kriterier.

De forskningsbaserede argumenter kan dog kollidere med en mere hverdagsagtig forståelse af, hvad der giver mening at bruge tid på som specialestuderende. Nogle studerende kan opleve det som spild af tid at skulle forberede feedback til andre - tid, der går fra arbejdet med deres eget speciale. Samtidig kan de være usikre på, om både den feedback, de modtager, og den, de giver, er kvalificeret nok (Kaufman \& Schunn 2011). Det kan medføre usikkerhed $\mathrm{i}$ forhold til at anvende feedbacken fremadrettet og tvivl om det meningsfulde $\mathrm{i}$ at engagere sig i peer-feedback-aktiviteter generelt. Den præsenterede model imødegår til dels disse mulige reservationer over for peer-feedback. Tidsmæssigt skal den studerende blot forberede feedback på en enkelt anden studerendes relativt korte tekst. Tvivl om, hvorvidt feedbacken er tilstrækkeligt kvalificeret, afhjælpes ved, at der tages udgangspunkt i den subjektive læserbaserede feedback (Elbow 1998), hvilken kan reducere eventuelle bekymringer om, hvorvidt man nu som feedbackgiver kan tilbyde tilstrækkeligt kvalificeret feedback. At vejle- 
deren samarbejder med feedbackgiver og de lyttende studerende om at bevæge sig fra læserbaseret feedback til identifikation af kriterier, kan være med til at skabe en tryghed i forhold til kriteriernes relevans og dermed det meningsfulde i feedback-aktiviteten. Endelig er det velkendt, at nogle studerende kan føle ubehag ved at dele deres tekster med medstuderende (Topping 1998; Hanrahan \& Isaacs 2001). Med sin forskydning fra fokus på den tekstproducerende studerende til feedbackgiver kan modellen være med til at lette et sådant ubehag. For i denne model er det feedbackgiver, der er i fokus og således ikke den tekstproducerende studerende, der skal indtage "den varme stol" over for vejlederen.

\section{Modellen kan fremme studerendes selvstondighed}

Selvstændighedsbegrebet spiller en central rolle i forhold til kandidatspecialet, og begrebet kan fortolkes på forskellige måder (Jensen 2018). Mange specialevejledere tillægger selvstændighedsbegrebet stor betydning og opfatter det som en væsentlig opgave at fremme studerendes selvstændighed undervejs i vejledningsprocessen. Det kan dog være en udfordring for vejlederen, at den studerende ikke nødvendigvis af sig selv påtager sig en aktiv, ansvarlig rolle i vejledningen, men i højere grad forholder sig som en passiv modtager (Anderson, Day \& McLaughlin 2006; Vereijken, van der Rijst, van Driel \& Dekker 2009). Denne udfordring søger modellen at imødekomme på især to måder:

For det første iscenesættes feedback-aktiviteten på en måde, der markerer at feedbackgivers forberedelse og aktive dialog med vejlederen er helt central og en forudsætning for et udbytterigt møde. De studerende afkræves så at sige en høj grad af selvstændighed i processen (Rienecker, Wichmann-Hansen \& Stray Jørgensen 2019), dvs. i deres engagement og aktive deltagelse i vejledningen og i den fælles samtale. Processen understøttes på forskellig vis: For eksempel er de forskellige roller og opgaver velafgrænsede, stolenes placering i rummet signalerer, hvad der skal ske, og endelig påtager vejlederen sig rollen med at stille opklarende og uddybende spørgsmål til de studerendes forståelse og læseroplevelse. Det er en pointe, at de studerendes selvstændighed (forstået som deres høje grad af engagement og aktive deltagelse i udvikling af kriterier) ikke blot forudsættes, men at struktureringen af aktiviteten også fungerer som en form for stilladsering, der hjælper de studerende med at opøve selvstændighed (forstået som kompetencer til at indgå i en aktiv faglig og kritisk dialog med peers og vejleder): Rollen med at give feedback til en anden medstuderende imiterer en autentisk faglig samtale mellem peers, som de senere forventes at kunne udøve selvstændigt som færdiguddannede.

For det andet inviteres de studerende (alle studerende - ikke kun den feedbackgivende studerende) også ind i en aktiv rolle i deres konkrete arbejde med at opøve akademiske skrivekompetencer, idet de ikke blot forventes at være passive modtagere af et allerede prædefineret sæt kriterier. Deres individuelle læseroplevelser tillægges værdi i sig selv og bruges som afsæt til at udvikle generelle kriterier for de forskellige fremstillingsformer. De studerende får derigennem mulighed for selv aktivt at diskutere kriterier og standarder, hvilket styrker deres dømmekraft og støtter dem i at tage ejerskab over egen læring. Denne proces er med til at træne, hvad Tai et al. (2018) kalder studerendes evaluative judgement, forstået som evnen til træffe kvalificerede beslutninger om eget og andres arbejde på egen hånd. Denne uafhængighed af vejledere eller lignende figurer er tæt forbundet med ideen om at opnå selvstændighed gennem uddannelse (Tai et al. 2018). Det er dog vigtigt at bemærke, at de studerende i den beskrevne model ikke er overladt helt til sig selv. Udvikling af kriterier sker med 
støtte fra vejlederen, som faciliterer diskussionen, korrigerer undervejs hvis nødvendigt og supplerer med viden om fagets genrekrav.

3. Modellen kan understøtte vejlederens dialogiske praksis og bygge bro mellem funktionen som procesvejleder og faglig vejleder

Det er en klassisk diskussion i vejledningslitteraturen, om vejlederen bør være en faglig vejleder eller en procesvejleder (Rienecker, Wichmann-Hansen \& Stray Jørgensen 2019). En faglig vejleder opfattes som en ekspert på den studerendes opgaveemne og vejleder primært på indhold. En procesvejleder opfattes som en repræsentant for disciplinen og kan vejlede i generelle akademiske krav til skriftlige fremstillinger og i planlægning af opgave- og skrivearbejdet. Efter fremdriftsreformen oplever mange vejledere, at de i højere grad end før reformen bliver begrænset til rollen som procesvejleder, fordi de får tildelt studerende ud fra en administrativ logik og ikke ud fra et fagligt match mellem ekspertise og opgaveemne (BagerElsborg, Herrmann \& Wichmann-Hansen 2018). Modellen, som vi har beskrevet her, kan ikke afhjoelpe problemet med, at vejledere begrænses til procesvejledere, men den kan udnytte de nye betingelser. Det bærende princip i modellen er netop, at fokus er fjernet fra det specifikke faglige indhold for en stund. Formålet er at stille skarpt på centrale akademiske fremstillingsformer og få tydeliggjort ikke bare, at der er bedømmelseskriterier for et speciale (jf. studieordningen), men også hvordan man konkret kan læse sin tekst og vurdere, hvorvidt man lever op til de pågældende kriterier. Dermed kan modellen hjælpe med at sætte fokus på forventninger til den akademiske genre, og på hvordan man kan indfri disse - ikke bare i vejledningen, men også fremadrettet i den studerendes opgaveskrivningsproces.

I vejledningslitteraturen er det også en kendt og velbeskrevet udfordring for mange vejledere at balancere mellem på den ene side at agere faglig autoritet og skulle rådgive og kvalitetssikre og på den anden side at understøtte studerende i at være aktive forberedte aktører i at drive deres egen undersøgelse og opgave fremad (Wichmann-Hansen, Thomsen, \& Nordentoft 2015; Wichmann-Hansen \& Herrmann 2017). Dysthe og Samara (2006) skelner mellem tre modeller for vejledning: undervisermodellen, partnerskabsmodellen og lærlingemodellen. De beskriver, at selvom mange vejledere udtrykker ønske om at arbejde inden for en partnerskabsmodel (karakteriseret ved dialog, fælles ansvar og en symmetrisk relation), så ender de ofte med at handle inden for undervisermodellen (karakteriseret ved monolog, underviseren som ekspert og en asymmetrisk relation). Selv om man som vejleder har et ønske om ikke at "undervise" i sin vejledning, så kan det altså være svært at realisere i praksis - ikke mindst fordi mange studerende vil efterspørge denne form for vejledning (Dysthe \& Samara 2006). Den beskrevne model for brugen af peer-feedback i kollektiv vejledning kan støtte vejlederen i ikke at falde tilbage i underviserrollen i vejledningen. For den iscenesættelse og rollefordeling, der ligger i modellen, bevirker ikke kun, at studerende inviteres ind $\mathrm{i}$ en mere aktiv position. Modellen rammesætter også vejledningssituationen på en måde, der fordrer, at vejlederen påtager sig en dialogisk og faciliterende rolle. Hvis vejlederen "falder tilbage" i en underviserrolle, så får det synlige konsekvenser, idet modellen så ganske enkelt ikke kan gennemføres. Modellen kan dermed støtte vejlederen i at opøve en mere dialogisk vejledningspraksis og samtidig give øverum til at træne spørgsmålstyper, der skaber refleksion og læring hos den studerende (Wichmann-Hansen \& Jensen 2013). 


\section{Konklusion}

Vi har i denne artikel beskrevet en konkret model for, hvordan peer-feedback kan organiseres i kollektiv vejledning. Modellen er foreløbig afprøvet i et enkelt semester på fire specialestuderende på et psykologisk institut, og selvom tilbagemeldingerne fra de studerende er positive, er data for sparsomme til, at vi alene på det grundlag kan argumentere for modellens brugbarhed. Vi har i stedet argumenteret for modellens styrker i et teoretisk perspektiv med inddragelse af veletableret forskningslitteratur om vejledning og feedback. Vi har også i artiklen forsøgt at redegøre for modellen så detaljeret og kontekstualiseret, at læseren har mulighed for selv at vurdere modellen og at inkorporere hele eller dele heraf $\mathrm{i}$ egen vejledningspraksis.

Hidtil har litteraturen på feltet mest understreget vigtigheden og værdien af peer-feedback samt metodens potentiale i kollektiv vejledning. Vores artikel bidrager med et konkret bud på, hvordan man kan organisere peer-feedback i kollektiv vejledning på en måde, der både er nytænkende og teoretisk velbegrundet. Det nytænkende ligger ikke i at invitere de studerende til at udvikle kriterier, da det er velbeskrevet som didaktisk greb i litteraturen, men derimod i at facilitere udviklingen af kriterier ved at sætte fokus på den feedbackgivende studerende og dennes dialog med vejlederen. Vi har argumenteret for, at modellen kan hjælpe med at realisere det læringspotentiale, som ifølge forskningslitteraturen ligger i peerfeedback. Vi har vist, at modellens stærke fokus på at give feedback kan bidrage til at stilladsere studerendes selvstændige arbejde med at udvikle, anvende og genkende fagets akademiske kriterier. Uden støtte og metoder hertil kan det ellers være vanskeligt for studerende på egen hånd at få et ordentligt udbytte af peer-feedback. Samtidig har modellen potentiale til at understøtte vejlederen $i$ at arbejde dialogisk $\mathrm{i}$ sin vejledningspraksis og derigennem fremme de studerendes selvstændighed og dømmekraft.

En væsentlig indvending mod modellen er, at der kun arbejdes med kriterier for udvalgte fremstillingsformer - i dette tilfælde "redegørelse" og "diskussion". Men modellen indebærer i princippet ingen begrænsninger for, hvor mange og hvilke fremstillingsformer, der skal arbejdes med i de kollektive vejledningsmøder. Det må være op til den enkelte vejleder at afgøre, hvad faget, eksamensformen, tidsrammen og andre kontekstuelle faktorer muliggør.

En anden væsentlig indvending mod modellen er risikoen for en vis tilfældighed i de producerede kriterier, da kriterierne er afhængige af, hvad der kendetegner den enkelte studerendes tekst til det pågældende møde. Med stor sandsynlighed er der andre genrekriterier for fx en "diskussion", der er vigtige for studerende at kende til, end dem, der bliver aktualiseret i det pågældende møde. Denne udfordring eller kritik kan vejlederen dog imødekomme ved 1) at metakommunikere til de studerende, at der ikke er tale om en endegyldig bruttoliste af kriterier og 2) at henvise de studerende til publikationer om skriftlig fremstilling mere generelt, fx veletablerede håndbøger (Rienecker \& Stray Jørgensen 2017; Skov 2008).

Andre potentielle svagheder ved modellen er af logistisk og kontekstuel karakter. Med hensyn til logistik er modellen ikke egnet til kollektiv vejledning med mange studerende. Det er tidskrævende at udvikle kriterier som en del af et vejledningsmøde, og det kan potentielt blive kedeligt for studerende at være lyttende observatører uden en egentlig funktion. Generelt er rådet fra litteraturen om kollektiv vejledning, at formen kan drives med 2+ studerende, men en ideel gruppestørrelse er 4-5 (Rienecker et al, 2019). Samme råd må gælde i denne situation. Vi vil dermed ikke anbefale, at modellen bruges på gruppestørrelser over ca. 5 studerende. Derudover kan vejledere forsøge at afhjælpe problemet med "kedelige" observatør- 
roller ved 1) at give de studerende observationsopgaver, fx. "Notér de kriterier, som kommer frem, og læs dem højt til sidst" eller "Giv til sidst i mødet et eksempel på, hvordan kriterierne kan appliceres på din egen opgave: Hvor opfylder du dem, og hvor gør du ikke?". I denne model vil studerende dog med stor sandsynlighed lytte opmærksomt og ikke passivt, da drøftelserne og samtalerne i vejledningsmødet ikke har et snævert fagspecifikt indhold, men i stedet handler om generelle kriterier for akademisk fremstilling, som er dybt relevant for alle de studerendes specialer.

Med hensyn til kontekst må man kritisk spørge, om modellen også vil være relevant på andre fag end psykologi? Vi medgiver, at der kan være fag, hvor udvikling af kriterier 1) enten vil være en overflødig aktivitet, fordi kriterierne er velkendte hos de studerende, eller 2) en uegnet aktivitet, fordi det er for fremmed og krævende for studerende at udvikle kriterier, hvorfor aktiviteten ikke kan rummes inden for vejledningens tidsramme eller formål. Men vores bud er, at selvom modellen er udviklet i en specifik faglig kontekst, betyder det ikke, at den er begrænset til det psykologiske fagområde. Tværtimod har modellen potentiale til at understøtte peer-feedback i kollektiv vejledning på tværs af mange faglige kontekster. Mange fag oplever ligesom psykologifaget udfordringer med at få vejledning til at fungere under øget tidspres og kollektive rammer, ligesom de efterlyser mere selvstændighed hos studerende, øgede akademiske skrivekompetencer og metoder til at få studerende til at engagere sig i peer-feedback-aktiviteter.

Endelig kan modellen tjene som eksempel på, hvordan vejledere kan bruge deres egne fags metoder som en ressource og inspiration til udvikling af vejledningspraksis. "Den varme stol" og "reflekterende teams" er velkendte arbejdsmetoder i psykologisk professionspraksis. I andre discipliner vil andre metoder være mere nærliggende og fagligt relevante. Det kunne fx. være scrum-metoden i ingeniørfag ( $f x$ ved at planlægge arbejdet i sprints og have fokus på løbende tilpasning af projektmål, se evt. Parner \& Wichmann, 2015), laboratorieformater i kliniske fag eller casemetoden i erhvervsøkonomiske fag, som kunne inspirere til nye vejledningsmodeller. Måske viser denne disciplinforankrede tilgang ligefrem en ny vej for udvikling af vejledningsområdet som helhed, hvor ikke kun almenpædagogiske metoder sætter kursen?

\section{Referencer}

Anderson, C., Day, K. \& McLaughlin, P. (2006). Mastering the Dissertation: Lecturers' Representations of the Purposes and Processes of Master's Level Dissertation Supervision. I: Studies in Higher Education, 31(2), 149-168.

Andersen, T. (1994). Reflekterende processer: samtaler og samtaler om samtalerne. København: Dansk psykologisk Forlag.

Bager-Elsborg, A., Herrmann, K.J. \& Wichmann-Hansen, G. (2018). Hvad er konsekvensen af fremdriftsreformen for specialevejledere? Paper præsenteret på DUN konferencen d. 17. maj, Vejle, Danmark

Cho, K. \& MacArthur, C. (2011). Learning by reviewing. Journal of Educational Psychology, 103(1), 73-84. 
Dysthe, O., Samara, A. \& Westrheim, K. (2006). Multivoiced supervision of Master's students: a case study of alternative supervision practices in higher education. Studies in Higher education, 31(03), 299-318.

Elbow, P. (1998). Writing with power: Techniques for mastering the writing process. Oxford: Oxford University Press.

Gibbs, G. (1999) Using assessment strategically to change the way students learn, in: S. Brown \& A. Glasner (Eds) Assessment Matters in Higher Education: Choosing and Using Diverse Approaches. Buckingham: SRHE/Open University Press.

Griffith, B.A. \& Frieden, G. (2000). Facilitating reflective thinking in counselor education. Counselor Education and Supervision, 40(2), 82-93.

Hanrahan, S. J. \& Isaacs, G. (2001). Assessing self-and peer-assessment: The students' views. Higher Education Research \& Development, 20(1), 53-70.

Hvass, H. \& Heger, S. (2018). Brugbar peer feedback: Instruktion og træning, før de studerende selv skal give og modtage. Dansk Universitetspoedagogisk Tidsskrift, 13(25), 59-70.

Jensen, H.N. (2015) Opgave- og skrivevejledning i klynger. Håndbog for undervisere og vejledere på videregående uddannelser. Frederiksberg: Forlaget Samfundslitteratur

Jensen, T. W., Bay, G. \& Andersen, P. (2016). Udvikling af studerendes akademiske skrivekompetencer - en indsats på fakultetsniveau. In DUN: Dansk Universitetspoedagogisk Konference 2016.

Jensen, T.W. (2018). Det danske universitetsspeciale - topografi, tekster og tendenser.Aarhus: Aarhus Universitetsforlag.

Kaufman, J.H. \& Schunn, C.D. (2011). Students' perceptions about peer assessment for writing: their origin and impact on revision work. Instructional Science, 39(3), 387-406.

Lea, M.R. \& Street, B.V. (1998) Student writing in higher education: An academic literacies approach. Studies in higher education,23(2), 157-172.

Nicol, D.J., Thomson, A. \& Breslin, C. (2014). Rethinking feedback practices in higher education: a peer review perspective. Assessment \& Evaluation in Higher Education, 39(1), 102-122.

Nicol, D.J. \& Macfarlane-Dick, D. (2006). Formative assessment and self-regulated learning: a model and seven principles of good feedback practice. Studies in Higher Education, 31(2), 199-218.

Nordentoft, H. M., Hvass, H. og Mariager-Anderson, K. (2018) Kollektiv Akademisk Vejledning. Fra forskning til praksis. Aarhus: Aarhus Universitetsforlag.

Nordentoft, H. M., Thomsen, R. \& Wichmann-Hansen, G. (2013). Collective academic supervision: a model for participation and learning in higher education.Higher Education, 65(5), 581-593.

Parner, E. \& Wichmann-Hansen, G. (2015). Ph.d.-vejledning er mere end faglig vejledning. I: Lotte Rienecker \& Peter Stray Jørgensen (Red.) Universitetspaedagogiske praksisser. Forlaget Samfundslitteratur, pp. 257-80. 
Perls, F.S., Hefferline, R. \& Goodman, P. (1951). Gestalt Therapy. Excitement and growth in the human personality. New York, NY: Julian Press.

Rienecker, L. \& Stray Jørgensen, P. (2017) Den gode opgave - håndbog i opgaveskrivning på videregående uddannelser. Frederiksberg: Forlaget Samfundslitteratur.

Rienecker, L., Wichmann-Hansen, G. \& Stray Jørgensen, P. (2019). God vejledning af specialer, bacheloropgaver og projekter. Frederiksberg: Forlaget Samfundslitteratur.

Samara, A. (2007). Group supervision in graduate education: a process of supervision skill development and text improvement. Higher Education Research and Development, 25(2), 115-129.

Skov, S. (2008). Bundne opgaver. Frederiksberg: Forlaget Samfundslitteratur.

Tai, J., Ajjawi, R., Boud, D., Dawson, P. \& Panadero, E. (2018). Developing evaluative judgement: enabling students to make decisions about the quality of work. Higher Education, 76(3), 467-481.

Topping, K. J. (2017). Peer assessment: learning by judging and discussing the work of other learners. Interdisciplinary Education and Psychology, 1(1), 1-17.

Topping, K. (1998). Peer assessment between students in colleges and universities. Review of educational Research, 68(3), 249-276.

Upton, D. \& Trapp, A. (Eds.). (2010). Teaching psychology in higher education. Oxford, UK: John Wiley \& Sons.

Vereijken, M.W.C., van der Rijst, R.M., van Driel, J.H. \& Dekker, F.W. (2018). Novice Supervisors' Practices and Dilemmatic Space in Supervision of Student Research Projects. I: Teaching in Higher Education, 23 (4), 522-542.

Wanner, T., \& Palmer, E. (2018). Formative self-and peer assessment for improved student learning: the crucial factors of design, teacher participation and feedback, Assessment \& Evaluation in Higher Education, 43(7), 1032-1047

Wichmann-Hansen, G., \& Jensen, T. W. (2013). Processtyring og kommunikation i vejledningen. In L. Rienecker, P. Stray Jørgensen, J. Dolin \& G. Holten Ingerslev (red) Universitetspæ-dagogik (pp. 329-350). Frederiksberg: Forlaget Samfundslitteratur.

Wichmann-Hansen, G., Thomsen, R., \& Nordentoft, H.M. (2015). Challenges in Collective Academic Supervision: supervisors' experiences from a Master Programme in Guidance and Counselling. Higher Education,70(1), 19-33

Wichmann-Hansen, G., \& Herrmann, K.J. (2017). Does external funding push doctoral supervisors to be more directive? A large-scale Danish study. Higher Education, 74(2), 357-76. 